\title{
Assessment of personnel motivation as an effective tool for ensuring the success of food industry enterprises
}

\author{
Yulia Verchenko ${ }^{1, *}$, Anna Borisova ${ }^{2}$, Olga Bruzhukova $^{3}$ \\ ${ }^{1}$ Don State Technical University, 1, pl. Gagarina, 344002, Rostov-on-Don, Russia \\ ${ }^{2}$ Polytechnic Institute (branch) of the Don State Technical University in Taganrog, 109a, Petrovskaya \\ str., 347904, Taganrog, Russia \\ ${ }^{3}$ All-Russian state University of justice (RPA of the Ministry of justice of Russia), 50, str. 14-line, \\ 344019, Rostov-on-Don, Russia
}

\begin{abstract}
The article touches upon the issues related to the study of assessing the personnel motivation in the food industry approach. We describe an approach to assess the level of the working group motivation, which allows us to determine the level of sufficient motivation of personnel and assess its impact on the organization success. The algorithm, methodology and results of the research on the practical study of criteria for qualitative and quantitative evaluation of the subsystems effectiveness of motivation control, material incentives for employees, the process of personnel regulation, management of the reserve for promotion, the subsystem of personnel evaluation and its development are presented.
\end{abstract}

\section{Introduction}

To ensure the effective functioning of food industry enterprises in the modern world, it is important to conduct a systematic analysis of resource use, including studying and evaluating human resource management [1-4]. The study of modern researchers' articles [5-8] is grounded on identifying a more acceptable method for evaluating the effectiveness of the motivation system in personnel management for food industry enterprises as a key tool for optimizing the use of human resources. The study identified a set of shortcomings that cause difficulties in using existing methods for evaluating motivation. These disadvantages include [9-12] the lack of evaluation criteria for most indicators, difficulty in accurate calculation, and the lack of evaluation indicators for various management subsystems (personnel reserve, personnel development). The results of the study allowed us to structure the principles laid down in approaches to personnel management that are acceptable for food industry enterprises into four groups: expert assessment, comparison of costs and economic effects, benchmarking, and analysis of socio-economic factors of activity [13-16]. However, the use of these principles in the basis of the methodological approach is complicated by the lack of the ability to determine separately the effectiveness of all components of the personnel management system. The purpose of the study is to

* Corresponding author: u_verchenko@mail.ru 
develop an approach to assessing the motivation of a small working group of food industry enterprises, as well as to study the criteria for performance in modern market conditions and economic realities.

\section{Materials and methods}

The effectiveness of forming and controlling the level of motivation can be defined as the ratio of the actual level of employees motivation to the level at which the working group is sufficiently motivated to succeed. Determining the actual level of food industry employees' motivation or a separate division (department) can be carried out using the method of determining the level of the working group motivation, which involves the assessment of every subject 25 pairs of statements describing various aspects of interaction in the team during the work process. The assessment is based on a 7-point scale. The sum of all points on every questionnaire characterizes the level of participants' motivation of the workforce. The study involves a survey of a focus group of employees in order to reliably determine the level of motivation, which is calculated as an arithmetic average for all employee questionnaires points.

The described indicators of food companies' motivation level of personnel and criteria for evaluating the effectiveness of their personnel management [12] are presented in the table. 1. To get a numerical estimate of personnel management effectiveness, we assigned points to the qualitative characteristics of the indicators. In this case, the lowest efficiency corresponds to 1 point, the highest- to 3 points. In order to obtain a summary assessment of personnel management effectiveness, we assigned a score to the quality characteristics of the above six indicators, in which the lowest efficiency corresponds to 1 point, the highestto 3 points.

Table 1. The system of indicators for evaluating the effectiveness of personnel management in the food industry.

\begin{tabular}{|c|c|c|c|}
\hline $\begin{array}{c}\text { The process of } \\
\text { personnel } \\
\text { management }\end{array}$ & Indicators & Criteria for the process effectiveness & $\begin{array}{l}\text { Number of } \\
\text { points }\end{array}$ \\
\hline \multirow{4}{*}{$\begin{array}{l}\text { Formation and } \\
\text { control } \\
\text { motivation }\end{array}$} & \multirow[t]{4}{*}{ E1 } & E1 $<0.534$ - extremely inefficient & 1 \\
\hline & & $\begin{array}{l}0.534<\text { E } 1<0.902 \text { - insufficiently } \\
\text { effective }\end{array}$ & 1.75 \\
\hline & & $0.902<\mathrm{E} 1<1.090$ - quite effective & 2.25 \\
\hline & & E1 > 1.090 - maximally effective & 3 \\
\hline \multirow{4}{*}{$\begin{array}{l}\text { Financial } \\
\text { stimulation }\end{array}$} & \multirow[t]{4}{*}{ E2 } & E2 $<0.706$ - extremely inefficient & 1 \\
\hline & & $\begin{array}{l}0.706<\text { E2 }<0.907 \text { - insufficiently } \\
\text { effective }\end{array}$ & 1.75 \\
\hline & & $0.907<\mathrm{E} 2<1.076$ - quite effective & 2.25 \\
\hline & & E2 $>1.076$ - maximally effective & 3 \\
\hline \multirow{3}{*}{$\begin{array}{l}\text { Personnel } \\
\text { management }\end{array}$} & \multirow[t]{3}{*}{ E3 } & E3 $<0.1 ;$ Tperiod $=90$ days - effective & 3 \\
\hline & & $\begin{array}{l}0.1<\mathrm{E} 3<0.25 ; \text { Tperiod }=90 \text { days- } \\
\text { insufficiently effective }\end{array}$ & 2 \\
\hline & & $\begin{array}{l}\text { E3 }>0.25 \text {; Tperiod }=90 \text { days- extremely } \\
\text { inefficient }\end{array}$ & 1 \\
\hline \multirow{3}{*}{$\begin{array}{l}\text { The personnel } \\
\text { reserve } \\
\text { management }\end{array}$} & \multirow[t]{3}{*}{ E4 } & $\mathrm{E} 4<0.75$ - extremely inefficient & 1 \\
\hline & & $\begin{array}{l}0.75<\mathrm{E} 4<1 \text { or E4 }>1.5 \text { - insufficiently } \\
\text { effective }\end{array}$ & 2 \\
\hline & & $1<\mathrm{E} 4<1.5$ - effective & 3 \\
\hline \multirow{3}{*}{$\begin{array}{l}\text { Personnel } \\
\text { assessment }\end{array}$} & \multirow[t]{3}{*}{ E5 } & E5 $<0.9$ - extremely inefficient & 1 \\
\hline & & $0.9<$ E5 $<0.99$ - insufficiently effective & 2 \\
\hline & & E5 $>0.99$ - effective & 3 \\
\hline
\end{tabular}




\begin{tabular}{|l|l|l|l|}
\hline \multirow{2}{*}{$\begin{array}{l}\text { Personnel } \\
\text { training }\end{array}$} & \multirow{2}{*}{ E6 } & E6 $<10-$ extremely inefficient & 1 \\
\cline { 3 - 4 } & & $10<\mathrm{E} 6<16-$ insufficiently effective & 2 \\
\cline { 3 - 4 } & & E6 $>16-$ effective & 3 \\
\hline
\end{tabular}

Determination of the summary assessment of personnel management effectiveness is made by finding the average point, according to the table. 1 . The following qualitative characteristics of the personnel management system effectiveness are proposed:

- the efficiency is extremely low with a result of from 1.0 to 1.75 inclusive;

- the effectiveness is not high enough if the score is over 1.75 to 2.25 points;

- the efficiency is characterized as high with a score of more than 2.25 to 3.0 points.

Thus, the developed methodology allows us to evaluate the effectiveness of personnel management activities based on the completeness of the personnel management service functions by identifying six key indicators for the implementation of tasks in the context of competencies, and to obtain a summary assessment of motivation effectiveness. For this purpose, data from internal statistics and materials from the sociological survey of personnel are used. This allows to get a differentiated score and quality assessment of the implementation effectiveness of personnel management individual processes, as well as to evaluate the activities of the personnel management service of the organization as a whole. Monitoring the dynamics of the six proposed indicators allows performing a factor analysis of changes in the effectiveness of personnel management individual processes of the organization.

\section{Results}

In order to test the proposed methodology for monitoring the implementation of personnel management processes, the research was conducted on the basis of seven food industry enterprises operating in the Rostov region. Based on the initial data, 6 resulting indicators were calculated (table. 1). The results of these calculations are presented in the table. 2.

The selected cells indicate the potential for improving performance across all evaluation indicators.

Based on the criteria for the corresponding indicators presented in the table 4, we conducted a qualitative analysis of the effectiveness of human resource management subsystems (table. 3).

Table 2. Values of performance indicators for evaluating the system of personnel motivation in the food industry of the Rostov region.

\begin{tabular}{|c|c|c|c|c|c|c|}
\hline Organization number & E1 & E2 & E3 & E4 & E5 & E6 \\
\hline 1 & 1.105 & 1.092 & 0.090 & 1.100 & 0.988 & 13.000 \\
\hline 2 & 0.881 & 0.924 & 0.200 & 0.700 & 0.800 & 12.000 \\
\hline 3 & 0.903 & 0.992 & 0.190 & 0.800 & 0.800 & 12.000 \\
\hline 4 & 0.800 & 0.723 & $0.370-$ & 0.800 & 0.625 & 8.000 \\
\hline 5 & 0.910 & 0.756 & 0.200 & 0.900 & 0.000 & 10.000 \\
\hline 6 & 1.040 & 1.008 & 0.240 & 1.050 & 1.000 & 9.000 \\
\hline 7 & 1.119 & 1.109 & 0.220 & 1.000 & 0.974 & 16.000 \\
\hline
\end{tabular}


Table 3. Qualitative characteristics of the effectiveness of evaluating personnel motivation system in the food industry of the Rostov region.

\begin{tabular}{|c|c|c|c|c|c|c|}
\hline \multirow{2}{*}{$\begin{array}{c}\text { Organizati } \\
\text { on number }\end{array}$} & $\begin{array}{c}\text { Formation } \\
\text { and } \\
\text { control of } \\
\text { motivation }\end{array}$ & $\begin{array}{c}\text { Material } \\
\text { stimulatio } \\
\mathbf{n}\end{array}$ & $\begin{array}{c}\text { Personnel } \\
\text { manageme } \\
\text { nt }\end{array}$ & $\begin{array}{c}\text { The } \\
\text { personnel } \\
\text { reserve } \\
\text { manageme } \\
\text { nt }\end{array}$ & $\begin{array}{c}\text { Personnel } \\
\text { assessment }\end{array}$ & $\begin{array}{c}\text { Personnel } \\
\text { training }\end{array}$ \\
\hline 1 & $\begin{array}{c}\text { maximally } \\
\text { effective }\end{array}$ & $\begin{array}{c}\text { maximally } \\
\text { effective }\end{array}$ & $\begin{array}{c}\text { maximally } \\
\text { effective }\end{array}$ & effective & effective & effective \\
\hline 2 & $\begin{array}{c}\text { insufficient } \\
\text { ly effective }\end{array}$ & $\begin{array}{c}\text { quite } \\
\text { effective }\end{array}$ & $\begin{array}{c}\text { quite } \\
\text { effective }\end{array}$ & $\begin{array}{c}\text { insufficientl } \\
\text { y effective }\end{array}$ & $\begin{array}{c}\text { extremely } \\
\text { inefficient }\end{array}$ & $\begin{array}{c}\text { insufficient } \\
\text { ly effective }\end{array}$ \\
\hline 3 & $\begin{array}{c}\text { quite } \\
\text { effective }\end{array}$ & $\begin{array}{c}\text { quite } \\
\text { effective }\end{array}$ & $\begin{array}{c}\text { quite } \\
\text { effective }\end{array}$ & $\begin{array}{c}\text { insufficientl } \\
\text { y effective }\end{array}$ & $\begin{array}{c}\text { insufficient } \\
\text { ly effective }\end{array}$ & $\begin{array}{c}\text { insufficient } \\
\text { ly effective }\end{array}$ \\
\hline 5 & $\begin{array}{c}\text { insufficient } \\
\text { ly effective }\end{array}$ & $\begin{array}{c}\text { insufficient } \\
\text { ly effective }\end{array}$ & $\begin{array}{c}\text { insufficientl } \\
\text { yeffective }\end{array}$ & $\begin{array}{c}\text { extremely } \\
\text { inefficient }\end{array}$ & $\begin{array}{c}\text { insufficient } \\
\text { ly effective }\end{array}$ & $\begin{array}{c}\text { extremely } \\
\text { inefficient }\end{array}$ \\
\hline 6 & $\begin{array}{c}\text { quite } \\
\text { effective }\end{array}$ & $\begin{array}{c}\text { insufficient } \\
\text { ly effective }\end{array}$ & $\begin{array}{c}\text { insufficientl } \\
\text { yeffective }\end{array}$ & $\begin{array}{c}\text { insufficientl } \\
\text { y effective }\end{array}$ & $\begin{array}{c}\text { insufficient } \\
\text { ly effective }\end{array}$ & $\begin{array}{c}\text { extremely } \\
\text { inefficient }\end{array}$ \\
\hline 7 & $\begin{array}{c}\text { quite } \\
\text { effective }\end{array}$ & $\begin{array}{c}\text { quite } \\
\text { effective }\end{array}$ & $\begin{array}{c}\text { quite } \\
\text { effective }\end{array}$ & $\begin{array}{c}\text { insufficientl } \\
\text { y effective }\end{array}$ & effective & effective \\
\hline effective & $\begin{array}{c}\text { maximally } \\
\text { effective }\end{array}$ & $\begin{array}{c}\text { maximally } \\
\text { effective }\end{array}$ & $\begin{array}{c}\text { insufficientl } \\
\text { y effective }\end{array}$ & effective & effective \\
\hline
\end{tabular}

The results of the calculation show the problem areas in the activities of the studied organizations and allow forming solutions for adjusting the motivational program of small group employees in particular and upgrading the motivation system in general.

\section{Discussion of the results}

Modernization of food industry personnel motivation system which includes the stages of description, design and implementation of changes, avoids the consequences associated with the introduction of new tools for various types of incentives (fig. 1).

According to the algorithm presented in the figure 1, tactical solutions for upgrading the motivation system have been developed, taking into account the identified qualitative performance characteristics. 


\section{STAGE. Description}

Analysis of the existing incentive system

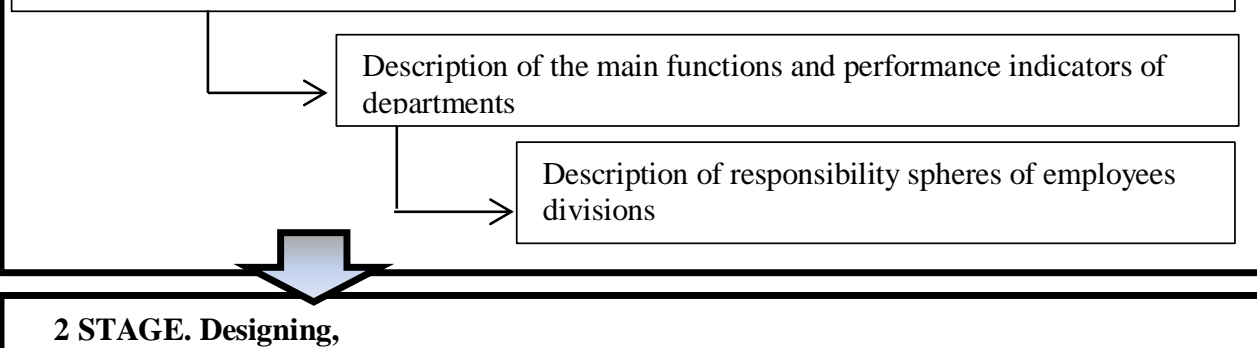

2 STAGE. Designing,

Creating a target behavior model for every employee

\section{STAGE. Implementation}

Adjustment of the order of interaction between employees and their job responsibilities

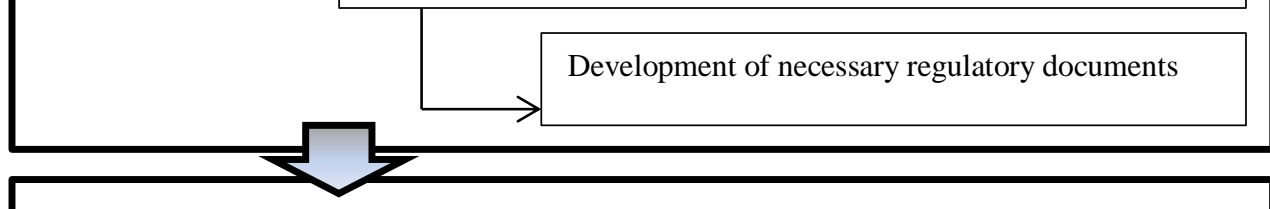

Experimental calculation of premiums using a new method

Implementation of the methodology in APC

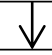

Adjusting the new motivation system

Monitoring the dynamics of employee motivation levels

Replication of the motivation system in all APC

Fig. 1. Stages of reforming the system process of personnel motivation in the food industry.

\section{Conclusions}

In order to identify opportunities for evaluating the dynamic development of the motivation system, we recalculated the indicators in the table 1 and formulated the changed qualitative characteristics of the performance of management subsystems. The new data is presented in the tables 4-5. The obtained information shows the correction of indicators as a result of tactical actions of the proposed algorithm for improving the motivation system. 
Table 4. Values of performance indicators of the personnel management system of food industry enterprises in the Rostov region.

\begin{tabular}{|c|c|c|c|c|c|c|}
\hline Organization number & E1 & E2 & E3 & E4 & E5 & E6 \\
\hline 1 & 1.105 & 1.092 & 0.090 & 1.100 & 0.988 & 13.000 \\
\hline 2 & 0.963 & 0.924 & 0.090 & 0.920 & 0.954 & 12.000 \\
\hline 3 & 0.903 & 0.992 & 0.190 & 0.800 & 0.932 & 12.000 \\
\hline 4 & 0.920 & 0.965 & $0.180-$ & 0.800 & 0.985 & 11.000 \\
\hline 5 & 0.910 & 0.911 & 0.176 & 0.900 & 0.861 & 10.000 \\
\hline 6 & 1.040 & 1.008 & 0.105 & 1.050 & 1.000 & 12.000 \\
\hline 7 & 1.119 & 1.109 & 0.096 & 1.000 & 0.974 & 16.000 \\
\hline
\end{tabular}

Table 5. Qualitative characteristics of the effectiveness of personnel management subsystems of food industry enterprises in the Rostov region.

\begin{tabular}{|c|c|c|c|c|c|c|}
\hline \multirow[b]{2}{*}{$\begin{array}{c}\text { Organizatio } \\
\text { n number }\end{array}$} & \multicolumn{6}{|c|}{ Qualitative characteristic } \\
\hline & $\begin{array}{c}\text { Formatio } \\
n \text { and } \\
\text { control of } \\
\text { motivatio } \\
n \\
\end{array}$ & $\begin{array}{c}\text { Material } \\
\text { stimulatio } \\
\text { n }\end{array}$ & $\begin{array}{c}\text { Personnel } \\
\text { manageme } \\
\text { nt }\end{array}$ & $\begin{array}{c}\text { The } \\
\text { personnel } \\
\text { reserve } \\
\text { manageme } \\
\text { nt } \\
\end{array}$ & $\begin{array}{c}\text { Personnel } \\
\text { assessment }\end{array}$ & $\begin{array}{c}\text { Personnel } \\
\text { training }\end{array}$ \\
\hline 1 & $\begin{array}{c}\text { maximall } \\
y \\
\text { effective }\end{array}$ & $\begin{array}{l}\text { maximally } \\
\text { effective }\end{array}$ & $\begin{array}{l}\text { maximally } \\
\text { effective }\end{array}$ & effective & effective & effective \\
\hline 2 & $\begin{array}{c}\text { quite } \\
\text { effective }\end{array}$ & $\begin{array}{c}\text { quite } \\
\text { effective }\end{array}$ & $\begin{array}{c}\text { quite } \\
\text { effective }\end{array}$ & $\begin{array}{l}\text { insufficientl } \\
\text { y effective }\end{array}$ & $\begin{array}{l}\text { extremely } \\
\text { inefficient }\end{array}$ & $\begin{array}{l}\text { insufficientl } \\
\text { y effective }\end{array}$ \\
\hline 3 & $\begin{array}{c}\text { quite } \\
\text { effective }\end{array}$ & $\begin{array}{c}\text { quite } \\
\text { effective }\end{array}$ & $\begin{array}{c}\text { quite } \\
\text { effective }\end{array}$ & $\begin{array}{l}\text { insufficientl } \\
\text { y effective }\end{array}$ & $\begin{array}{l}\text { insufficientl } \\
\text { y effective }\end{array}$ & $\begin{array}{l}\text { insufficientl } \\
\text { y effective }\end{array}$ \\
\hline 4 & $\begin{array}{c}\text { quite } \\
\text { effective }\end{array}$ & $\begin{array}{c}\text { quite } \\
\text { effective }\end{array}$ & $\begin{array}{c}\text { quite } \\
\text { effective }\end{array}$ & $\begin{array}{c}\text { quite } \\
\text { effective }\end{array}$ & $\begin{array}{c}\text { quite } \\
\text { effective }\end{array}$ & $\begin{array}{c}\text { quite } \\
\text { effective }\end{array}$ \\
\hline 5 & $\begin{array}{c}\text { quite } \\
\text { effective }\end{array}$ & effective & effective & effective & effective & $\begin{array}{c}\text { quite } \\
\text { effective }\end{array}$ \\
\hline 6 & $\begin{array}{c}\text { quite } \\
\text { effective }\end{array}$ & $\begin{array}{c}\text { quite } \\
\text { effective }\end{array}$ & $\begin{array}{c}\text { quite } \\
\text { effective }\end{array}$ & $\begin{array}{c}\text { quite } \\
\text { effective }\end{array}$ & effective & effective \\
\hline 7 & $\begin{array}{c}\text { maximall } \\
y \\
\text { effective }\end{array}$ & $\begin{array}{l}\text { maximally } \\
\text { effective }\end{array}$ & $\begin{array}{l}\text { maximally } \\
\text { effective }\end{array}$ & $\begin{array}{l}\text { quite } \\
\text { effective }\end{array}$ & effective & effective \\
\hline
\end{tabular}

Thus, we can evaluate the effectiveness of the methodology and its feasibility for small working groups of food industry enterprises as a key indicator of human resource optimization processes.

\section{References}

1. B. Ozkeser, Procedia Computer Science 158, 802-810 (2019) doi.org/10.1016/j.procs.2019.09.117

2. P. Soltantabara, H. Farsijanib, M. Bazazic, Procedia - Social and Behavioral Sciences 25, 802-810 (2011) doi.org/10.1016/j.sbspro.2011.10.525

3. L. Rincon-Ballesteros, G. Lannelongue, J. González-Benito, Motivations and barriers 106, 106715 (2019) doi.org/10.1016/j.foodcont.2019.106715

4. M. Song, S. Wang Jing Sun, Technological Forecasting and Social Change 133, 1-14 (2018) doi.org/10.1016/j.techfore.2018.04.020

5. N. Martyushev, E. Sinogina, U. Sheremetyeva, Procedia - Social and Behavioral Sciences 166, 265-269 (2015) doi.org/10.1016/j.sbspro.2014.12.522 
6. A. Azadeh, M. Zarrin, Safety Science 89, 55-71 (2016) doi.org/10.1016/j.ssci.2016.06.001

7. S. Dehghani, A. Gharooni, A. Arabzadeh, S. Empowerment, Procedia - Social and Behavioral Sciences 109, 1130-1141 (2014)

8. J. Álvarez-García, M. de la Cruzdel Río-Rama, M. Saraiva, A. Ramos Pires, Journal of Cleaner Production 185, 62-74 (2018) doi.org/10.1016/j.jclepro.2018.03.023

9. G. Van Hecken, P. Merlet, M. Lindtner, J. Bastiaensen, Ecological Economics 156, 519-529 (2019) doi.org/10.1016/j.ecolecon.2016.12.030

10. D. Safina, A. Bikchantaeva, Procedia Economics and Finance 27, 404-408 (2015) doi.org/10.1016/S2212-5671(15)01012-6

11. O. Zaikin, M. Malinowska, N. Bakhtadze, A. Żyławski, Procedia Computer Science 112, 1092-1101 (2017) doi.org/10.1016/j.procs.2017.08.131

12. V. Freitas, M. Duarte, Tékhne 1(2), $\quad 88-99 \quad$ (2017) doi.org/10.1016/j.tekhne.2017.11.002

13. K.A. Barmuta, A.A. Borisova, M.P. Glyzina, Mediterranean Journal of Social Sciences 6(3S4), 91-96 (2015) doi: 10.5901/mjss.2015.v6n3s4p91

14. V.V. Mazur, K.A. Barmuta, S.S. Demin, E.A. Tikhomirov, M.A. Bykovskiy, International Journal of Economics and Financial Issues 6 (1S), 270-274 (2016)

15. K. Barmuta, V. Ponkratov, M. Maramygin, N. Kuznetsov, V. Ivlev, M. Ivleva, Entrepreneurship and Sustainability Issues 7(1), 484-497 (2019) doi: 10.9770/jesi.7.1(34)

16. N.S. Plaskova, N.A. Prodanova, A.S. Samusenko, E.A. Erzinkyan, K.A. Barmuta, R.A. Shichiyakh, International Journal of Engineering and Advanced Technology 9(1), 2913-2916 (2019) doi:10.35940/ijeat.A1213.109119 